\title{
Work of the Forestry Commission*
}

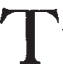
HE 'forest year' of the Forestry Commission ends on September 30, and that date in 1931 brought to a close the twelfth year of its work. It was inevitable that operations and a policy that are dependent upon Government grants and a present non-productive expenditure should have been subject to a close scrutiny from the May Committee on National Expenditure.

For the second decade of the Commission's work, it had been estimated that the gross cost of the whole business (purchase of land, planting, etc.) and the ancillary operations such as assistance to private forestry, education, research, etc., would amount to $£ 11,275,000$ for the decade; working receipts were estimated at $£ 2,160,000$ and the net contribution from the Exchequer was expected to be $£ 9,115,000$. The chief objectives laid down during the second decade were to plant 353,000 acres and to establish 3,000 worker's holdings. The planting programme was to be on an expanding scale, beginning with 25,000 acres in 1929 and rising to 44,000 acres in 1938 , while the holdings programme was to be at the rate of 350 holdings yearly for the first five years, and 250 holdings yearly for the second five years. In order to carry out these programmes, it would be necessary to acquire each year 6,000 acres of plantable land and 2,500 acres of agricultural land.

It has been already stated in Nature (Sept. 17, 1932, p. 427) in a note discussing a paper by Sir John Stirling-Maxwell on "Forestry and National Economy" that the sum sanctioned for the above proposals received a severe cut at the hands of the May Committee, the majority report making the following recommendation: "After weighing up all these considerations we recommend that no fresh acquisitions of land be made for the present and that no more forest worker's holdings be created, but that afforestation proceed at the rate of 20,000 acres per annum for five years on the land already acquired. This course is estimated to save $£ 478,000$ next year and $£ 560,000$ per annum in subsequent years as compared with the present policy."

In subsequent discussions with the Government, the Commissioners stated that it was desirable to maintain the main elements of forest policy, which were, briefly, the continuance of planting and of the acquisition of plantable land, and the provision of sufficient houses and holdings to work the forests economically. After due consideration, the Chancellor of the Exchequer undertook that the Government would provide annually for the next five years the sum of $£ 450,000$ which, with working receipts, would enable the Commissioners to spend rather less than $£ 600,000$ a year on forestry operations.

With this sum at their disposal, the Commissioners anticipate that they will be able to carry out the following work: (1) Maintain a planting programme of 20,000 acres a year. (2) Acquire sufficient plantable land to keep intact the reserve of land which is required for maintaining the planting programme. (3) Provide sufficient forest worker's holdings (numbering perhaps 15-20 a year) for working the forests efficiently, and also repair and maintain such holdings as are necessary for the utilisation of the nonplantable land. (4) Provide grants for planting on

* Forestry Commission. Twelfth Annual Report of the Forestry Commissioners for the Year ending Sept. 30, 1931. Pp. 43. (London: H.M. Stationery Office.) $9 d$. net. the same scale as during the last three years. (5) Maintain intact their research activities and make suitable provision for forestry education and other ancillary activities.

The question of forestry on private estates has been receiving the attention of the Commissioners, and the Consultative Forestry Committees of England, Scotland and Wales were consulted and a joint report presented. This report stated that private forestry is not receiving the same attention as in pre-War days, in spite of the spread of technical knowledge and State encouragement. The causes for the decline during post-War years are admitted and well known to all. In the urgent need for national economy the joint report was unable to suggest any general solution. The Commissioners appear to be of opinion that the State, in the long run, might have to relieve the private owner of his responsibility in maintaining the woodlands of Great Britain.

Apart from the question as to whether this is a correct policy, either for the State or the tax-payer, it is open to doubt whether it is even a truly economic one. In France the State forests form about a third only of the total forest area, in Sweden 20 per cent and in Germany 25 per cent. With a reduction of taxation in Great Britain, with the available technical knowledge and the advantage of the presence in the country of the Forestry Commission, it may be hoped that the land owner will find it possible to follow in the footsteps of his confrères on the Continent. The disappearance of the private forest owner was evidently not contemplated by Lord Clinton, during his tenure of the chairmanship of the Commission. In an address delivered at the annual meeting in 1928 of the Royal Scottish Arboricultural Society (see NATURE of May 5, 1928, p. 697) Lord Clinton said : "I am not at all confident that the State can properly undertake the full duties of afforestation. I think the keenness of the general public, who in theory are very keen on forestry, is likely to evaporate directly they begin to understand the great cost which will fall on them if the State shoulders the whole burden."

Soon after the close of the year under review, the chairman of the Commission, Sir John StirlingMaxwell, resigned. Of his work for Great Britain in the cause of forestry and that of his two predecessors, Lord Lovat and Lord Clinton, it is impossible to speak too highly. Sir Roy Robinson, a technically trained forester, now assumes the chairmanship. In spite of the fears of some well qualified to speak when the Forestry Bill was passed in 1919, there is little doubt that the new Forestry Department was only able to weather the stormy times of its first twelve years owing to its fortunes being in the hands of three such able and powerful land owners as the past triumvirate of chairmen.

The Report deals in general with the work of the year ending September 1931. The net total area of land acquired in Great Britain to this date was 627,075 acres, of which 393,448 acres were classified as plantable, 58 per cent being in England and Wales and 42 per cent in Scotland. The area planted during the year was 25,630 acres, the total area planted during the twelve years being 188,985 acres, of which 177,456 acres consisted of conifers and 11,529 acres of hardwoods.

An interesting item in the Report is the valuation 
by the Inland Revenue authorities of the Crown properties transferred from the Office of Woods to the Forestry Commission. The chief of these were the New Forest and the Forest of Dean, the total valuation of which amounts to $£ 1,227,495$.

Under education and research the Report sum- marises the conclusions of the Irvine Committee on the training of candidates for Government forest services. The Commissioners pass no comment upon these conclusions which, it is understood, are receiving the careful consideration of the universities concerned.

\section{Harvey and Preventive Medicine}

A BRIEF account of Sir George Newman's Harveian Oration to the Royal College of Physicians of London appeared in NatuRE shortly after its delivery (NATURE, Oct. 29, p. 657). The full text of the discourse has since been published in pamphlet form.*

In his discussion of the new physiology which was inaugurated by Harvey's demonstration of the mechanism of the circulation of the blood, Sir George Newman points out that in 1622, six years after Harvey's first Lumleian discourse and six before his book was published, the demonstration of the lacteals and lymphatic system by which nutriment reached the blood was made by Aselli, Pecquet and Rudbeck. In 1648 the chemistry of digestion and the blood was investigated by van Helmont. Ten years later, the corpuscles of the blood were discovered by Swammerdam and Malpighi, and in 1661 Malpighi revealed the existence of the capillaries, which had been suspected by Harvey who, in the absence of a microscope, had been unable to detect them. In 1669 the contributions to the physiology of respiration by Boyle, Hooke, Mayow and Richard Lower demonstrated the purpose and process of aeration of the blood in the lungs, its selective use of the oxygen in the air, its conveyance to the tissues by the blood, and the resulting vitality and functioning of the tissues.

In the succeeding century, the actual gases which control life - carbonic acid, nitrogen and oxygen-were separated and fresh knowledge of the nervous and digestive systems was acquired. In the middle of the nineteenth century the foundations of endocrinology were established by the work of Thomas Addison, Claude Bernard and Brown-Séquard, and since then the progress of physiology in Great Britain has been pre-eminent in quantity, quality and scope.

Sir George Newman next considers the application of these discoveries to preventive medicine. He points out that from the sixteenth century onwards, the research worker has collaborated with the private practitioner and the public medical officer in the prolongation of life and the prevention of disease.

* "The Debt of Preventive Medicine to Harvey and the College of Physicians." (Harveian Oration, 1932: The Royal College of Physicians of London.) By Sir George Newman. Pp. 47. (The British Periodicals Ltd., 19 Cursitor Street, E.C.4.) 1s. net.
Striking examples of this statement are furnished in the eighteenth century by Lind and Sir Gilbert Blane in their defence of the health and the dietary of seamen, by William Cadogan, the pioneer in maternal and child welfare, and Sir John Pringle, who reformed the health of the Army. In recent times the labours of modern physiologists have con. tributed not only to the conservation of health but also to the prevention and cure of disease, as is exemplified by their work in connexion with cretinism, goitre, diabetes, anæmia, malnutrition, deficiency diseases, beri-beri, osteomalacia, scurvy and rickets.

The study of the cause and control of infective diseases is taken by Sir George Newman as another example of the Harveian method and spirit. The conveyance of infection by the circulating blood was acknowledged by Harvey's contemporaries, such as Glisson and Sydenham in the seventeenth century, and by the eighteenth century physicians who explored the circumstances and clinical features of infective diseases and observed their relation to external environment, to seasons and to meteorological conditions. Examples of such men were Huxham, who investigated typhoid, typhus, Devonshire colic, scurvy and scarlet fever; Heberden, who studied chicken-pox, measles and epidemic colds; Fothergill, who described epidemic sore throat; Haygarth, well known for his work on small-pox and typhus ; Edward Jenner, who introduced vaccination, and Willan, the father of British dermatology. It is noteworthy that in spite of the absence of any exact knowledge of the causation of disease, which was not reached until the advent of bacteriology in the later half of the nineteenth century, two significant conquests were achieved by the English before the end of the eighteenth century in the control of scurvy and of small-pox.

The production of artificial immunity, which Sir George Newman rightly regards as the greatest single advance in preventive medicine, is chosen by him as yet another example of the application of the Harveian method. Although the protective qualities of the blood were known to Harvey, it is only within comparatively recent times that an explanation of this property has been found, thanks to the work of Pasteur, Lister, Metchnikoff and Sir Almroth Wright.

\section{Spreading of Liquids on Solid Surfaces}

$\mathrm{I}^{\mathrm{T}}$ is generally supposed that on metals as well as on water the fatty oils and fatty acids should possess a more pronounced spreading tendency than the mineral oils, yet experiments show that this is not the case. Buckley and Snyder (J.Amer. Chem. Soc., Jan.) have confirmed this observation and have discovered an interesting phenomenon of rupture of thin layers of liquid on a solid surface due to the instability created by an underlying adsorbed film of low surface energy. Fatty oils and fatty acids lower the static coefficient of friction between metal surfaces more than do mineral oils of the same viscosity, and a mineral oil containing a small percentage of a fatty acid lowers the friction almost as much as a pure fatty oil. This is in agreement with a preferential adsorption of fatty acid on the metal surface, indicating that these acids lower the surface tensions of metals more than do mineral oils.

Mineral oils which spread rapidly on ordinary metal surfaces seem to have no spreading tendency on a metal surface covered with an invisible fatty acid film. When a drop of petroleum oil containing 